\section{Manning Formula}

Jeffrey R. Keaton

Amec Foster Wheeler, Los Angeles, CA, USA

\section{Definition}

The Manning formula is an empirical relationship to define depth-averaged velocity of water flowing in open-channel conditions $(\bar{v})$ to hydraulic radius $(R)$, slope of the energy grade line $\left(S_{e}\right)$, and channel roughness $(n)$, which is known as Manning's $n$ value. Open-channel conditions are under the influence of gravity without pressure forcing water movement. In engineering geology application, natural river and stream channels are of most interest; however, the Manning formula also applies to canals and pipes, provided that pressure flow does not occur. The Manning formula is

$$
\bar{v}=\frac{1}{n} R^{\frac{2}{3}} S_{e^{\frac{1}{2}}}
$$

where $\bar{v}$ is in $\mathrm{m} / \mathrm{s}, R$ is in $\mathrm{m}$ (cross-section area, $A$, divided by wetted perimeter, $P$ ), and $S_{e}$ is in $\mathrm{m} / \mathrm{m}$, resulting in $n$ having the units of $\mathrm{s} / \mathrm{m}^{1 / 3}$ for $\bar{v}$ in US customary units (ft/s), a conversion factor of $1.486=\sqrt[3]{3.281 \mathrm{ft} / \mathrm{m}}$ is needed. The channel geometry typically can be measured or estimated; the energy grade line is more challenging to determine and commonly it is approximated by the slope of the channel. Manning's $n$ value is complicated and guidance for estimating it uses components related to channel irregularities, variations in channel cross section, obstructions in the channel, vegetation in and adjacent to the channel, and channel meandering characteristics (Arcement and Schneider 2005).

The Darcy-Weisbach formula for turbulent flow and the equivalent Chézy equation use an absolute value of roughness $\left(k_{s}\right)$ in $\mathrm{m}$, which represents the size of irregularities on the channel bed and banks. Comparing these formulas with the Manning formula reveals that Manning's $n$ value is not a constant for a particular stream channel, but varies with hydraulic radius $(R)$ (Kruger 2006).

$$
n=\frac{R^{\frac{1}{6}}}{18 \log \left(\frac{12 R}{k_{s}}\right)}
$$

\section{Cross-References}

$$
\begin{aligned}
& \text { Alluvial Environments } \\
& \text { Chezy Formula }
\end{aligned}
$$

\section{References}

Arcement GJ Jr, Schneider VR (2005) Guide for selecting Manning's roughness coefficients for natural channels and flood plains. United States Geological Survey Water-supply Paper 2339, metric version. http://www.fhwa.dot.gov/bridge/wsp2339.pdf. Accessed May 2016

Kruger E (ed) (2006) Drainage manual. The South African National Roads Agency Limited. http://www.citg.tudelft.nl/fileadmin/ Faculteit/CiTG/Over_de_faculteit/Afdelingen/Afdeling_Bouw/Secties/Sectie_Weg_en_Railbouwkunde/-_Leerstoelen/LeerstoelWegbouwkunde/__Onderwijs/__College_Dictaten/doc/Drainage_ Manual.pdf. Accessed May $20 \overline{16}$ 